\title{
Two Paths for Innovation: Parvenu or Pariah
}

\author{
Antony Bryant \\ Leeds Metropolitan University
}

\begin{abstract}
"The intuitive mind is a sacred gift and the rational mind is a faithful servant. We have created a society that honors the servant and has forgotten the gift."
\end{abstract}

Albert Einstein

\begin{abstract}
In recent years the innovator has invariably been seen as an entrepreneur, wedded to a market philosophy that extends beyond any narrow confines of business or commerce, becoming all pervasive. With regard to the public and third sectors, there was some justification for this as a useful corrective to an over-centralized concept of government which almost by definition precluded genuine innovation and enterprise. On the other hand, there was always the concomitant danger that the balance sheet would gradually efface any concerns with issues such as social justice and inequality. Recent state interventions resulting from the credit crunch and general concerns with financial liquidity, have dramatically altered the focus on the relationship and balance between the private, public, and third sectors. This in turn, requires a revised understanding of innovation and entrepreneurship across all sectors of society, as well as highlighting the role played by ICT.
\end{abstract}

Keywords: Innovation, Entrepreneurship, Social Entrepreneurship, Civil Society, Liquid Modernity, Hannah Arendt, Zygmunt Bauman, Albert Camus, Peter Drucker, Karl Polanyi, Jean-Baptiste Say, Joseph Schumpeter.

\section{Introduction}

Many years ago, when Calvin Coolidge returned from a church service he told his wife that the sermon had been on the topic of sin. His wife asked him what the minister had said; opting for brevity, Coolidge replied; 'On the whole he was against it'. Conversely, someone giving a presentation on creativity and innovation would, on the whole, be in favour of them. In recent years this auspiciousness has been virtually unchallenged, particularly with the concepts becoming increasingly allied with a business-like orientation to the world in general. This is exemplified in the call for papers for this workshop which included the phrase 'leveraging the intelligence and creativity of SMEs': Also the ways in which terms such as 'social innovation', 'social enterprise', and 'social entrepreneur' have gained currency and kudos. Innovation is seen as 'a good thing' - understood primarily in business terms; moreover this approach is understood to have applicability to virtually all aspects of everyday life. 
During the period from the end of the bursting of the DotCom bubble (2001), which itself coincided with the dissipation of endeavours connected with Y2K (remember that?), until at least the latter half of 2007, discussion of innovation and creativity took place against a backdrop of seemingly endless economic growth, in part founded on increasingly sophisticated use of ICT/IS. ${ }^{1}$ Indeed the DotCom bust began to recede, both in time and significance, against an apparently inexorable tale of innovation and growth that extended from the early 1990s into a future promising nearglobal prosperity. This was accompanied by a belief that the best way in which to foster innovation and creativity was to reduce regulation and centralized control, giving free rein - or reign - to the market; encouraging the private sector to participate in or even take control of what had traditionally been thought of as specifically public sector responsibilities.

By the middle of this decade there was a strong clamour for these trends to be expanded on a global scale; although there was an equally vociferous counter force which claimed that such unfettered markets lead to increased disparities in wealth, ever-increasing injustice and inequality, and significant propensities for unrest and discord. The former proved to be very much more powerful and influential - Davos won out over Porto Alegre. ${ }^{2}$ The result was an ever-shrinking public domain, while whatever remained of the public sector was increasingly market-oriented. This led to diminishing opportunities for collective and social action. Yet at the same time there was a general expansion in the number and role of NGOs and Civil Society Organizations [CSOs]. Governments were keen to reduce the size and scope of their public sector and associated expenditure, but the issues of social justice, equality, security and basic living standards did not disappear; on the contrary, in many cases they were exacerbated, often leaving the voluntary sector, NGOs and other CSOs as the last safety net or recourse for those cast aside, as the welfare state, in any meaningful and universal sense, was replaced by something more akin to a Dickensian one.

Against this context the concepts of innovation and creativity took on important new features; specifically becoming wedded to the development and promotion of enterprise and entrepreneurialism in the public sector and civil society in general. Moreover such civil society projects and third sector initiatives came to be judged in terms of their ambition, innovation and initiative - criteria emanating from the domain of the commercial entrepreneur: Hence the concept of the Social Entrepreneur.

\section{The Social Entrepreneur}

Social entrepreneurs can be seen as those who work on social issues and public sector projects, linking ideas of innovation, creativity, and change to a business-oriented

\footnotetext{
${ }^{1}$ For the purposes of what follows and given the CFP which alludes to 'IS', I shall treat the technological aspect (ICT) as coterminous with the systems aspect (IS). Thus phenomena such as ERP, CRM, E-Commerce, E-Government exemplify different forms of this combination.

${ }^{2}$ Davos being the location of the annual gathering of the rich and powerful - The World Economic Forum; Porto Alegre on the other hand hosts The World Social Forum, and is itself famous as a city that has fostered participatory budgeting and aims at redistributive democracy. See respectively http://www.weforum.org/en/index.htm http://www.portoalegre2002.org/homepage.html.
} 
approach. But in itself this is not sufficient; it simply stresses the second term at the expense of the first. If there is a really social weight to the appellation then there must also be some clearly delineated ethical stance, giving a distinctively social and collective orientation to such endeavours. If this aspect was not obvious before the current economic meltdown - credit crunch, sub-prime crisis, or whatever term is preferred then there can be little justification for ignoring it under the present circumstances. ${ }^{3}$

In what follows, an effort will be made to outline the context against which this association of entrepreneurialism and civil society has been invoked, and the implications of this linkage; also the ways in which recent economic developments now necessitate its re-examination. In turn, this will demand clarification and revision of the concepts of entrepreneurialism and of innovation in the context of civil society and society in general. The result will be to question whether or not innovation and creativity can be seen as best engendered by the desire for maximizing private gain: A position founded on the belief that "from this emerges the good-of-all" in the manner of Adam Smith's invisible hand - i.e. leading to the promotion of an end which was no particular person's intention. Perhaps it is now time to reconsider the entrepreneurial orientation, so that it involves a primary focus on the collective good with moral concerns from the outset. This will have implications for discussions about leveraging creativity and innovation, the nature of SMEs, and the role of ICTs.

\section{Innovation and Entrepreneurship}

These two terms are so obviously related that it is not surprising that they are often confused, and any distinction between them is lost. An authoritative source in recent decades that links the two is Peter Drucker's book Innovation and Entrepreneurship (1994), originally dating from the 1980s: Although as we shall see, Drucker demonstrates and perpetuates many shortcomings and misconceptions in his writing.

Drucker draws on the earlier work of Jean-Baptiste Say (1767-1832) and Joseph Schumpeter (1883-1950) in his discussion. He refers to Say's dictum that '[T]he entrepreneur shifts economic resources out of an area of lower and into an area of higher productivity and greater yield' (1994: 20). Say is credited with coining the term entrepreneur, although he also uses a term that can be translated as 'master-agent'. This aligns well with Drucker's argument that entrepreneurship is as much about effective management - of a particular sort - as it is about innovation. For Say, the primary determining factor of value was the usefulness placed on a commodity by the buyer. The entrepreneur was the agent who managed to identify new sources of untapped demand that could be met by new ways of combining the key three resources of land, labour and capital. ${ }^{5}$

\footnotetext{
${ }^{3}$ An equivalent point holds true for $\mathrm{AI}$ - which to date has proved far more artificial than intelligent.

${ }^{4}$ It is also often given as 'master-agent or adventurer'.

${ }^{5}$ Say is credited with introducing this three-fold distinction of resources. He is best known for Say's Law - 'supply creates its own demand'; he also translated Adam Smith's work into French, although he criticized the labour-theory of value as found, for example, in the work of Adam Smith; seeing it as misguided or incomplete, needing to be replaced by or complemented with a utility-oriented theory.
} 
For Say, this 'master-agent' offers a very specific form of expertise in an economy; an ability to act in ways in which existing resources can be re-combined in novel ways to produce higher returns and more effective use of resources, resulting in the final product having a higher utility value for potential buyers. Drucker develops this insight as a central part of his argument that entrepreneurship is something that should and can be systematized and taught, relying on a specific 'technology' which offers the perfect 'vehicle of this profound change in attitudes, values, and above all in behaviour' (1994: 13) - the technology 'is called management'.

Thus for Drucker, the entrepreneur is someone who changes or transmutes value; and writing for his readership in the late $20^{\text {th }}$ century Drucker wished to advance the idea that rather than simply waiting for such people to appear, it is necessary, feasible, and desirable to develop these activities in a systematic manner. Just as the haphazard and near-magical process of invention was transformed in the $20^{\text {th }}$ century into an institutionalized practice of research, and in particular of R\&D; so too must innovation and entrepreneurship be systematized and institutionalized. 'Entrepreneurs will have to learn to practise systematic innovation. ... Systematic innovation therefore consists in the purposeful and organized search for changes, and in the systematic analysis of the opportunities such changes might offer for economic or social innovation.' (1994: 30-31 - stress in the original - NB Drucker here clearly uses the term innovation to define a process not an artefact or outcome.)

\section{Schumpeter: The Entrepreneur as Super-Rational or Non-Rational?}

Joseph Schumpeter drew on Say's work in his arguments about the nature of entrepreneurship, and the 'creative destruction' that was the key feature of capitalism. Schumpeter's concept of the entrepreneur changed in the course of his writing, but the essential point of the role of entrepreneurship did not. The onward drive of capitalism emanated from the disturbances caused by entrepreneurial activities. Without entrepreneurship there would be stasis. In systems predating capitalism, entrepreneurship relied on specific individuals upsetting the status quo and releasing new potentialities; even in early capitalism this was still very much the case. Entrepreneurs were those people who created new possibilities, often going against conventional and accepted ideas. Although once the new ideas became the conventional ones, the entrepreneur might cease to act in this manner and become more of an executive or administrator; or might continue to act the entrepreneur, but now in contrast to the new form of what constituted the normal and the routine - 'the distinctive element is readily recognized so soon as we make clear to ourselves what it means to act outside the pale of routine. The distinction between adaptive and creative response to given conditions may or may not be felicitous, but it conveys an essential point; it conveys an essential difference.' (Schumpeter, quoted in Langlois 2002)

Some commentators such as Langlois (2002) have drawn the distinction between two conflicting strands in Schumpeter's work - either arguing that they coexist throughout his work, or differ between early and later writings: One strand centres on the argument that the spirit of the entrepreneur will gradually become obsolete as 
rational calculation encroaches further into everyday activities. ${ }^{6}$ If our knowledge increases, we can become more readily aware of the possibilities for innovation, and so rely less on the insights of the entrepreneurs. This implies that entrepreneurial insights make up for gaps or failings in current knowledge, so to an extent the entrepreneur is not only more insightful, but also more knowledgeable - i.e. supra-rational. Thus according to this view, potential innovations become more apparent with more knowledge. This implies a divergence between innovation and entrepreneurship, since as innovation, or the potential for innovation, increases, the need for or the call for entrepreneurship decreases.

The second strand is the exact opposite of this. Here the spirit of the entrepreneur will always be needed, because the ability to see things differently is precisely at odds with things as they are. This will apply however well-informed people might be. The key implication is that entrepreneurial insight is something non-rational; knowledge and rational calculation might be available, but there will always be a demand to go beyond the planned and the calculated, or at least to take an unorthodox and unconventional perspective.

This tension can be found in many writings on entrepreneurship and innovation; as well as embedded in many national and governmental policies designed to encourage such activities. Is the source of innovation and the entrepreneurial spirit to be found within the corporations and multi-nationals, with their plans and strategies centred on research departments and $R \& D$ budgets, or is this large-scale organization inimical to precisely these tendencies? Are the innovations of the future primarily to be found outside these large-scale organizations? Are large-scale organizations able to foster the process of innovation? Are SMEs the best sources of innovation, or should the sources and processes of innovations be sought beyond the confines of the private sector? Moreover how can the resources of the public and private sectors best be marshalled to ensure that such activities are encouraged and fostered? Are strategic plans designed to encourage innovation a contradiction in terms?

\section{Entrepreneurialism - Systematized or Situated?}

Drucker, writing in the 1980s and 1990s, argued in favour of systematizing entrepreneurship and innovation. He identified the five elements of the process of innovation, and linked these with a framework of opportunities for innovation set against an account of entrepreneurship practices and strategies. Peter Denning (2004), amongst others, has argued that, had Drucker's maxims been adhered to, the dotcom boom and bust might have been avoided. Yet this is not borne out either by a careful reading of Drucker's categories or by some reflection on the bases of the dotcom boom. Drucker's categories, although useful as guides, are far too ambiguous to serve as clear indicators in a fast-developing, fast-changing context. Furthermore, falling back on Say's position, those who acted in an entrepreneurial fashion at the start of the

\footnotetext{
${ }^{6}$ Schumpeter coined the term Unternehmergeist - usually translated as 'spirit of the entrepreneur' - although entrepreneurship seems a less clumsy form.

${ }^{7}$ A glance at Drucker's maxims in the light of the sub-prime fiasco indicates severe weaknesses in Drucker's position - but there is no space to develop this further at this juncture. See also Drucker's Top 10 Tips from 2005.
} 
dotcom boom were able to do so precisely because the resources were so readily available since companies and investors were falling over each other in the rush to ensure that resources were on tap for start-up dotcoms.

Drucker offers a number of examples of innovations and entrepreneurs, often reusing them in different ways to underline his main arguments. This fails to resolve the issue of the distinctions between invention, innovation, and entrepreneurship. Furthermore there is a paradox in pointing to past innovations as guides to future ones. Schumpeter is adamant that the entrepreneur sees things differently - creatively rather than adaptively; but the new situation that arises as a result of entrepreneurship is then the one that becomes commonplace; hence the response of many people to some innovation - 'Well I could have thought of that!'

It is noteworthy that Drucker omits any mention of invention, preferring to focus on the term innovation. Yet from the outset any reader might be confused by his various uses of the term. He defines innovation as

[a] specific tool of entrepreneurs, the means by which they exploit change as opportunity for a different business or a different service. It is capable of being presented as a discipline, capable of being learned, capable of being practised. Entrepreneurs need to search purposefully for the sources of innovation, the changes and their symptoms that indicate opportunities for successful innovation. And they need to know and to apply the principles of successful innovation. (1994: 17)

This clearly defines innovation as a process and a tool; one that entrepreneurs have to understand and employ. But what does Drucker mean by the term 'successful innovation'? In the context of a discussion of innovation, creativity, and entrepreneurship surely a successful innovation is one that has achieved success - however that might be defined - precisely after being subject to some entrepreneurial activity. This might be accomplished through a re-combination of resources to provide higher utility and greater effectiveness (Say), or as part of the process of creative destruction (Schumpeter). So entrepreneurship is the activity that ensures that an innovation becomes successful - in which case Drucker's invocation seems to be that entrepreneurs have to act as entrepreneurs; his definition is circular. On the other hand the first part of the extract implies that innovation itself is something distinct from entrepreneurship; the entrepreneur has to 'search purposefully' for the sources of innovation, and perhaps for the innovations themselves. The net result is that Drucker seems unable to distinguish between his two terms; hence his inability to separate them in one of his concluding remarks about the three factors which together 'make up innovation and entrepreneurship' (p233 - stress in the original) - these are purposeful innovation, entrepreneurial management, and entrepreneurial strategies. ${ }^{9}$

A careful reading of his book indicates that this is an understandable source of confusion, with Drucker acting as a master-agent re-combining two conceptual resources

\footnotetext{
${ }^{8}$ And the lead in to the sub-prime fiasco was even more marked an example of a context which impelled entrepreneurialism of a sort.

${ }^{9}$ Denning argues that Drucker does have a clear distinction - innovation is the search for opportunities, which then are transformed into practices and taken to the market place; entrepreneurship is the institutionalization of the practice of innovation in an organization.
} 
into a single term 'innovation-and-entrepreneurship'. The examples he uses throughout the book are illustrative of this; Gillette's pricing of safety razors and blades; Sony's application of transistor technology; public sector policies in Lincoln, $\mathrm{Ne}$ braska: All are used in various places throughout the book as examples of either innovation or entrepreneurialism, or both, depending on the point that Drucker wishes to make. The result is that the two become indistinguishable.

Moreover Drucker implies that his hybrid innovation-and-entrepreneurship is predominantly located within organizations - primarily in the private sector. He does seek to distance these activities from 'centralized planning', and so allow for individual idiosyncrasies. But largely the assumption is that the entrepreneurial spirit is one to be systematized within an organizational context; by default, the private corporate kind. Drucker evades some of the issues around this assumption with recourse to what he terms 'the entrepreneurial society' - but how this has come about, or exactly what it means is never clarified. The argument for this purposeful, systematized entrepreneurialism is ultimately incoherent; although it has been influential since it has come from the pen of Peter Drucker.

\section{Innovation and Invention}

A more helpful approach can be found in the work of John Howells (2005). His work focuses on innovation, with only passing reference to entrepreneurship; but in so doing he offers a far more profound analysis of the reality of the process itself. He distinguishes invention from innovation. Invention is defined as 'the generation of the idea of an innovation' (2005: 1) - which implies that an invention only becomes an innovation when it achieves some form of embodiment or actualization. This is similar to the work of Brian Winston (1998) whose model of invention is premised on the distinction between science or competence, and technology or performance. For Winston the move from competence to performance and beyond involves a series of socially mediated transformations. Just as Howells defines an invention as an idea, so Winston talks of ideation as the basis of the process of invention; although he sees this as including some initial move from competence to performance, at the very least demonstrating that the idea has some feasibility in the form of a prototype. Winston argues that the route from the laboratory into a wider context is often lengthy and always uncertain and precarious. Moreover the determining factor is rarely the nature of the invention itself, but rather what he terms 'supervening social necessity'. Howells develops this insight, albeit without reference to Winston, describing the process as a 'socio-cognitive' one - i.e. one with perceptual features as well as social ones. Winston, Howells and others stress that innovation must be seen as a situated process. Howells, in characterizing his approach offers a succinct description - 'A striking feature of the stories of invention was the role of social context and prior expertise for the cognitive act of insight. ... it seems important to capture the sense that social context and expertise influence the act of insight that is more commonly understood as the inventive process.' (2005: 33-34)

Howells gives detailed accounts of many innovations, showing how their route from conception to commonplace was far more complicated than is usually understood. In so doing he discusses the ways in which management within private firms 
acts both to promote and constrain innovation. His focus is specifically technological development, but his insights apply generally to the issues of the management of innovation. As he states in his preface

The overall object of the book is to convey an understanding of technology as immediately shaped by the firm, but situated in 'society' - and situated in the particular form of society that is the market economy, understood as the working set of institutions and governance procedures that have evolved to sometimes limit and sometimes enable technology-shaping decisions by management and entrepreneurs.

This is echoed by Manuel Castells in the introduction to The Information Age, where he offers a cogent dismissal of technological determinism.

Of course technology does not determine society. Nor does society script the course of technological change, since many factors, including individual intuitiveness and entrepreneurialism, intervene in the process of scientific discovery, technological innovation, and social applications, so that the final outcome depends on a complex pattern of interaction. Indeed the dilemma of technological determinism is probably a false problem, since technology is society, and society cannot be understood or represented without its technological tools.

The issue, addressed below, is: 'What kind of society?'

The work of those such as Howells and Winston offers a basis for grasping that innovation is a process that has to be understood in relationship to its social context; a situated practice with cognitive features and ramifications. This leads to three issues, amongst many others, that will be addressed in the remaining sections of this paper: What is the specific social context of the early $21^{\text {st }}$ century? Why is the concept of social entrepreneurship critical to our current context? How have recent economic upheavals altered the context and our understanding of terms such as innovation, creativity, and social entrepreneurship?

\section{The Current Context - Liquid Modernity}

Drucker used the term 'the entrepreneurial society', but offered nothing further other than that he hoped it would be a social context which encouraged and enhanced innovation-and-entrepreneurship. Howells locates innovation within the market economy, and Winston talks of the social forces that can either prevent innovations moving from the laboratory to the market place, or propel them there. But, particularly with regard to innovation, there are specific and critical characteristics of the current social context that are not brought out in the work of Howells, Winston and others. Say saw the entrepreneur as "necessary for the setting in motion of every class of industry whatever; that is to say, the application of acquired knowledge to the creation of a product for human consumption' (stress added). Schumpeter made similar claims, seeing entrepreneurship as the motor that propelled capitalism. The common 
implication is that without this impetus there would be stasis, or at best only restricted movement. This may have been the case in the past, but the current context is markedly different.

Zygmunt Bauman has labelled our current era as 'Liquid Modernity', which 'sets itself no objective, draws no finishing line, and assigns the quality of permanence solely to the state of transience. Time flows; but it no longer marches on to any destination'. Bauman's imagery of liquidity draws its resonance from The Communist Manifesto with its declaration - 'All that is solid melts into air, all that is holy is profaned, the need of a constantly expanding market for its products chases the bourgeoisie over the entire surface of the globe, it must nestle everywhere, settle everywhere, establish connections everywhere.' (see Bauman 2000: Foreword). The next sentence, not quoted by Bauman, continues thus: 'All fixed, fast frozen relations, with their train of ancient and venerable prejudices and opinions, are swept away, all newformed ones become antiquated before they can ossify.'

The declaration itself is paradoxical, and Bauman specifically draws our attention to this in his work. The idea of sweeping things away is an iterative and never-ending process. It is not simply a case of a once-and-for-all eradication of the old, and emergence of the new. The new rapidly becomes the old, and is itself swept away; and so on, indefinitely. The word 'liquidity' evokes the idea of flow, incessant movement, and change; it raises the question 'flow towards what'? But in the context of Liquid Modernity as Bauman characterizes it there is only flow away from the present, it has no ultimate destination or objective.

At this juncture, without seeking to offer any extended account of Bauman's recent work, the key points for present purposes are that; society may no longer need the powers of impulsion and momentum of the entrepreneur - at least not in the ways Say, Schumpeter, and Drucker envisaged them; the process of innovation needs to be re-examined, re-conceptualized and re-evaluated; our understanding of entrepreneurialism and the role of the entrepreneur will have to be revised and enhanced. This was already evident once one grasps Bauman's arguments, but is more so in the light of the sub-prime crisis and its aftermath.

\section{Innovation as an End in Itself}

In the context of Liquid Modernity, innovation is not the exception but the rule. There is an incessant demand for something new, purely because there is a craving for novelty, which, once delivered, rapidly becomes outdated; fit only for the scrap heap. Drucker's dream of an 'entrepreneurial society' has become a nightmarish reality, akin to Italo Calvino's city of Leonia which 'refashions itself every day'; with all the remains of yesterday 'encased in spotless plastic bags' placed carefully on the sidewalk waiting for the refuse collectors.

Drucker viewed such a society as comprising 'purposeful innovation, entrepreneurial management, and entrepreneurial strategies'. In the current context, innovation is indeed purposeful; paradoxically it has the prime purpose of being 'innovative', rather than meeting any actual need: The means has become an end in itself. In Say's terms, we might argue that the measure of utility is now innovation itself; with the supply of innovations now creating its own demand. Hence any innovative quality 
must have appeal first-and-foremost to the consumer, but this will be transitory. Noone wants yesterday's innovation; they want tomorrow's or at the very least today's. Schumpeter's concept of creative destruction becomes a cycle of creation-productionconsumption-disposal. This applies not only to the products and services themselves, as in Leonia, but also to the people and organizations involved in bringing them to market. ${ }^{10}$

The recent economic upheavals demonstrate that this cycle can extend not only to corporate giants such as Ford, General Motors, and Chrysler, but even to entire countries such as Iceland. Even prior to the third quarter of 2008, corporate strategies and management policies were creative-destructive, but usually with the destructive part falling on the shoulders of those working in or for the companies producing the innovations, rather than, as now seems to be the case, on entire companies themselves: Although companies that failed to heed this message were themselves destroyed or dismantled, often including those which until recently appeared to be well-established and long-lived. ${ }^{11}$

This might be taken to mean that there is now a free-for-all, with many innovations vying for market space to the ultimate benefit of all. This is often cited as one of the raisons d'être for policies that encourage SMEs, since they have the agility to respond swiftly to rapidly changing contexts, producing innovative ideas and strategies. But as Howells and others demonstrate, there is a tendency for innovations to become institutionalized inside large and powerful companies. This is something akin to Schumpeter's belief that eventually there will be a declining role for the entrepreneur, as knowledge and rational calculation are perfected; although in the context of research and innovation in corporations in the late 20th and early 21 st centuries this is not based primarily on the nature of knowledge but on control of resources, expertise and R\&D budgets. ${ }^{12}$ Thus, even the ability to develop competence, in Winston's sense, may be outside the scope of all but a few with access to the requisite resources: Performance is virtually unattainable by those outside the relevant institutional settings.

\section{The Great Transformation and the Double Movement}

On the other hand, against this background of increased concentration of a small number of 'master-agents or adventurers', and sources of and possibilities for innovation, there was, until recently, the parallel one of fragmentation as the centralizing and coordinating roles of the state and the public sector were dismantled. In many regards this

${ }^{10}$ And unlike the people of Leonia, the waste and detritus is not placed neatly into plastic bags as Sennett (1999) and Bauman (2004) make all too clear - the 'waste' from liquid modern society includes people as well as out-dated consumer goods.

${ }^{11}$ See Sennett 1999.

${ }^{12}$ This is not to rule out the role of serendipity and individual insight, but in many areas - e.g. medical research, bio-informatics, aeronautics, etc. - it is almost impossible to undertake anything beyond pure speculation and ideation outside the confines of the major corporations involved in those areas. Is this the way ahead for other aspects of research and innovation? It has even be noted that the outputs of $R \& D$ endeavours in some organizations produced inventions with no obvious market, until one is later created: And even inventions which are solutions to "problems "that did not exist prior to the invention itself. 
was a continuation of Karl Polanyi's Great Transformation ${ }^{13}$ (1944) whereby the selfregulating market gradually comes to take over all other aspects of social interaction and strategy, such that 'the market' is seen as something natural, inevitable, and universal. This lifts a great number of issues out of the realm of public debate and discourse, and the extent to which the great transformation developed above and beyond anything that Polanyi envisaged can be seen by the way in which the concept of the self-regulating market became the fons et origo or be-all and end-all for all manner of discourses and domains; including education, welfare, justice, and governance. Polanyi saw the creation of the modern economy and modern nation state as two parts of the same innovation, which he termed Market Society. Writing in 1940s as WWII was coming to a close, Polanyi was convinced that the post-war era would mark a qualitative move away from the cataclysm that had resulted from 'the utopian endeavour of economic liberalism to set up a self-regulating market system'. Unfortunately, precisely the opposite proved to be the case, in some countries after a brief interlude of centralized planning.

Polanyi's argument was that this transformation did not occur by force of nature, but rather as a result of institutional changes emanating from governments and powerful interests in the economy. Even the general acceptance of land, labour and capital as commodities was the result of a cognitive transformation; an example of Howells' concept of innovation with its stress on socio-cognitive changes. What Polanyi also argued, however, was that this continued colonization of everyday life by the selfregulating market was part of a double movement; whereby the force in favour of unfettered 'market forces' was tempered by moves towards increased intervention aimed at offsetting the excesses and evils that were unleashed by the market itself. Polanyi argued that prior to the Great Transformation 'production for gain' was held in check by 'production for use'; a distinction that Aristotle had made between 'householding proper' and 'production for gain'. This dichotomy is effaced once 'Market Society' emerges and develops in the 19th century.

Social solidarity was then dismantled, and the main unifying force put in its place was 'the market'. Moreover, what at first was a set of public policy recommendations, becomes seen as a force of nature, and the basis of natural order. When this does not seem to be working in a satisfactory manner, governments may try to take steps to intervene, either by dismantling constraints or imposing new ones. Sometimes both strategies are taken simultaneously to the consternation of all involved; and ultimately with diminished effect or unintended consequences. Polanyi pointed both at government policies projected to protect workers from poverty, and those to protect businesses from monopolies or other market developments. He defined the double movement as 'the principle of economic liberalism, aiming at the establishment of a self-regulating market ... [and] the principle of social protection aiming at the conservation of man and nature as well as productive organization'.

For the past few decades the double movement has clearly been slanted in favour of the self-regulating market; with some efforts enacted by governments to offset the

${ }^{13}$ Karl was the brother of Michael (Personal Knowledge), and uncle of John (Nobel Laureate for Chemistry). It would be useful if the IS world paid at least as much attention to Karl's work as they have to Michael's; and even better if the ideas of both were understood in a more nuanced manner. Michael's concept of tacit knowledge has been dreadfully misconstrued in much of the work on knowledge management. 
most palpable and blatant inequities. As the lure of the market has come to dominate all discourses, however, the extent to which governments and the public sector as a whole should take responsibility for its citizens has diminished, or been itself couched in market terms. One result has been an ironic twist to the double movement and great transformation; sometimes termed philanthro-capitalism or social entrepreneurship.

\section{Social Entrepreneurship}

Schumpeter's argument that the role of the entrepreneur will disappear as rational calculation extends into evermore aspects of social and economic life was never convincing; the limitations of 'rational planning' and 'perfectible knowledge' have always been evident, and his alternative concept of the entrepreneur as 'non-rational' was more persuasive. Yet the growing dominance of the market in ever-increasing aspects of society, particularly the public sector, seemed to portend the ultimate and universal applicability of business models - rational or otherwise. Moreover people could point to this encroachment or re-orientation as a source of new opportunities for innovation and entrepreneurial activities. Services and support activities that were once the monopoly of government or the state in one form or another were now being offered by private sector organizations and Civil Society Organizations [CSOs], or combinations of all three - public, private, and third sectors. In all cases the era seemed to be one where there was an unquestioned primacy for a business-oriented approach.

This was all part of a trend in many societies for private providers to take on many of the roles previously seen as inherently part of the public sector. ${ }^{14}$ Thus health, education, law enforcement and the like have increasingly been privatized. This has opened up opportunities for entrepreneurship in the public sector in Say's sense of refocusing resources in a new and more productive manner - although many of the claims that private provision of such services is more efficient, effective and profitable than public ones are widely challenged. (For present purposes, however, this is not the point at issue.) More important is the way in which the evolving relationship between different sectors of society brings to the fore the idea that entrepreneurship is not simply confined to the private sector. This has led to the use of the term 'social entrepreneurship' - also of 'philanthro-capitalism'. In some cases these are seen as ways of addressing social issues by linking ideas for public sector innovation and change to a business-oriented approach. Hence such comments as the following; 'The past two decades have seen an explosion of entrepreneurship and a healthy competition in the social sector, which has discovered what the business sector learned from the railroad, the stock market and the digital revolution: Nothing is as powerful as a big new idea if it is in the hands of a first class entrepreneur.'

This is entirely laudable, but it can quickly become simply another form of profitdriven entrepreneurship, shaking off any distinctively social and collective orientation. An example of this can be found on the website of The Institute for Social

\footnotetext{
${ }^{14}$ This has been seen as opening up a range of new opportunities for SMEs, although to a large extent provision has been dominated by large multinational and consortia. In any case it is equally important to understand that there needs to be a role for other organizational forms, including those developed bottom-up often in the manner of open source models of collaboration. I intend to develop this in further contributions at a later date.
} 
Entrepreneurs where a social entrepreneur is defined as 'any person, in any sector, who runs a social enterprise'; a social enterprise is "any organization, in any sector, that uses earned income strategies to pursue a double or triple bottom line, either alone (as a social sector business) or as part of a mixed revenue stream that includes charitable contributions and public sector subsidies'.

Even before the credit-crunch and ensuing bail-outs from the public purse undermined such statements, the overall ideas behind social entrepreneurship and philanthro-capitalism were far too restrictive. In many cases even the most 'successful' and visible exemplars were no more than small efforts to re-balance the excesses of the double movement that had swung so far in favour of the self-regulating market. Indeed as Michael Edwards (2008) points out in his extended critique of philanthrocapitalism, the figures used to proclaim its importance and impact are dwarfed by those of more conventional methods such as charities and the public sector per se. The key issue, which has become more evident and more important in the light of recent developments, is that the application of entrepreneurialism to civil society and the public sector has been far too inhibited and unimaginative: It needs to be far more wide-reaching and ambitious. This involves the realization that the concept of recombining resources in an ambitious and innovative manner needs to be applied well beyond the confines of a business model and the private sector - although it may still retain some aspects of this approach.

\section{SMEs, IS/ICT, Creativity, and Innovation}

The Call for Papers for this working group specifically links SMEs with IS/ICT, creativity and innovation: Also making mention of KM, knowledge transfer and various other terms lifted from the optimistic lexicon of business-as-usual - e.g. leveraging; although now ineluctably overtaken by intervening events. The general intent would appear to be that prevailing conditions are conducive to agility and change as long as the correct strategies and models can be articulated; in many cases such opportunities being rendered feasible through use of IS/ICT. There is, of course, no reason why the convenors of the workshop should have had any inkling of the dramatic events of the past few months, since almost no-one else did - even those allegedly with the relevant expertise. But even so, it is critical that we begin to dismantle this conceptual amalgam, questioning the implied linkages and opening up issues which otherwise might fall outside our purview (leaving aside, for the moment, who exactly is included in 'our').

The relationships between creativity, invention, innovation, and entrepreneurship need to be set against the current social context of liquid modernity - currently going through a crisis of illiquidity; building on and accounting for Winston's and Howells' respective ideas, and also offering a new understanding of Drucker, Say, and Schumpeter, amongst others. First it must be stressed that creativity is at work at all times and emanates from all manner of sources. Occasionally it finds form in invention, and some inventions become innovations, in line with Winston's concept of the transition from competence to performance. The arguments of Winston and Howells also have a further implication that needs to be grasped: Much creativity remains firmly wedded to the creator, never leading to innovation or a move into the market. This is well understood by Castells and Daniel Bell, both of whom use Harvey Brooks' definition of 
technology - 'the use of scientific knowledge to specify ways of doing things in a reproducible manner'. If an invention or ideation cannot be reproduced, in both the technical and economic senses of the term, it will not become an innovation; yet that is a necessary, but not sufficient condition.

In a society centred on the self-regulating market the transition from invention to innovation will necessarily involve entrepreneurship - in both Say's sense of the 'masteragent or adventurer' and Schumpeter's of 'creativity' rather than 'adaptivity'. But as Winston and Howells argue, such forces operate against a context of socio-economic characteristics that can impel or impede the move from competence to performance. In the current and extreme form of market society - Liquid Modernity - this entrepreneurship or adventurism runs amok. Everyone is encouraged, even prompted, to become an entrepreneur or a master-agent. The most successful being those able to find new ways of combining or leveraging the 'natural' resources of market society; what Polanyi terms the fictitious commodities of land, labour and capital. The result is that creativity, in its affirmative and imaginative, actually becomes divorced from innovation and entrepreneurship. The paradigmatic innovators-cum-entrepreneurs of early 21 st century liquid modernity are those financiers, hedge-fund managers, whiz-kids and maestros of arbitrage and other forms of transactional prestidigitation who have brought us to the current crisis. They have indeed transmuted value in Say's terms, shifting economic resources from lower into higher productivity and greater yield, but not in the substantive fashion that Say had in mind. Unfortunately the transmutation has proved as chimerical as that of the alchemists. There is no ultimate consumer whose needs are satisfied; only the chump finally left holding the 'assets' that are now revealed to be liabilities. The transmutation, if any, has been from lead to gold, rather than vice versa.

To an extent much of this innovation and entrepreneurialism, if not driven by the opportunities afforded by IS/ICT, has certainly benefited from the technology that facilitates and promotes the marshalling and consolidation of huge amounts of information, round-the-clock and near-instantaneous trading, infinitesimal transaction costs, all set against a global financial system that knows no boundaries and seemingly allows or even encourages evasion of all impediments and controls. ${ }^{15}$ Those advocating and encouraging the use of IS/ICT for all manner of improvements in efficiency and effectiveness have been far too ready to adopt and accept the breathless language of relentless encroachment of the market. In the IS/ICT academy we have been complicit with the chimerical innovators-cum-entrepreneurs who have proved to be the exact opposite of Schumpeter's concept. Rather than being creative and supra-rational, they have in fact been supra-adaptive and conventional; following the logic of the market in fictitious commodities, and ultimately producing fictitious and spectral innovations.

\section{The Entreprenuer: Pariah or Parvenu?}

The true role of the entrepreneur is to see things differently. Yet the entrepreneurs and innovators of liquid modernity appear to be the ultimate conformists; taking the concept of innovation as an end in itself to new extremes. In an age where we are all pressed to recreate ourselves on an almost daily basis, the entrepreneur has become the rule rather than the exception; and innovation has become the commonplace, the

${ }^{15}$ And if that fails, there is always straight forward mendacity, larceny, and dishonesty. 
routine and the humdrum: Oxymoronic as that may appear. This can be understood in terms of Hannah Arendt's concepts of the pariah and the parvenu (1951), and Albert Camus' distinction between two forms of rebellion (1951).

For Arendt, the parvenu is an upstart and a social climber: Someone who seeks to conform and so adapts to the established norms - stated and tacit - of the surrounding milieu; often excelling in performing whatever it is that is most highly regarded or rewarded. The parvenu is devoid of political ideas or wider social agendas, being entirely focused on personal interests and aggrandisement. The pariah on the other hand stands outside and apart from 'the conventional wisdom'; either by choice, or out of necessity: Arendt's initial discussion of the terms is couched in the context and her own experience of being Jewish in Germany in the 1920s and 1930s. The pariah sees things differently, which is both a precondition for and a result of being a pariah. The overall effect is that pariahs see the bigger picture, the social whole; often leading to utopianism, advocacy of social change, and political ideas that go beyond personal interests. The pariah often becomes the rebel.

Camus' discussion of rebellion brings out a further critical distinction, derived from his experience and observation of those who engaged with communism in the middle of the $20^{\text {th }}$ century. Those who saw the need for social change in terms aiming at perfection of society, based on some set of 'absolute values', were likely to follow even the most dictatorial and totalitarian tendencies and actual regimes. Camus termed this 'revolution' or 'historical rebellion'. While those who recognized the absurd, while still striving for change and improvement, engage in 'metaphysical rebellion', based on a lucidity that accepts the absurdity of the drama of social existence and the 'unreasonable silence of the world'.

Today we might understand Camus' concept of 'the absurd' in terms such as 'uncertainty', 'complexity' or 'chaos'; and this resonates with Bauman's Liquid Modernity particularly if, as I have argued elsewhere (Bryant,2007; Bryant et al 2007), the fluid metaphor is extended to incorporate a consideration of 'turbulence'. In terms of the current discussion, acceptance of absurdity or complexity effectively subverts any idea that perfection of knowledge and rationality will result in the demise of innovation and creativity - a reading of Schumpeter that sees the entrepreneur as suprarational - and instead heavily favours the alternative reading - the entrepreneur as non-rational. This leads to a focus on serendipity, rather than any misguided expectation of perfection or certainty.

So in the light of the credit-crunch, and the continuing exposure of the ways in which 'rational calculation' lay at the base of the fiasco in which we are all mired, it can be seen that many of the self-proclaimed entrepreneurs are parvenus rather pariahs; while the chorus of supporters, until recently urging general emulation of their efforts, are historical rebels quick to proclaim perfection and nirvana. To an extent this was understandable given the realities of Soviet-style Communism and its final demise, which exacerbated the enthusiasm for and growth of market society; on several occasions such has been its supremacy that many have heralded a new utopia of frictionless growth, universal prosperity, the end of boom and bust. Of course there were warnings from some sources, and even strong indications of precedents. $\mathrm{J} \mathrm{K}$ Galbraith, one of the most astute writers on economics, often warned that when people herald a new age of universal prosperity it is time to take cover. Bauman has referred to Emerson's dictum that when skating on thin ice, the only strategy is speed. 
What we now realize is that we are like those cartoon characters who continue on their way beyond the edge of the cliff, only falling once they look down to see that they have no visible means of support.

The current solutions to this crisis appear to be very much more-of-the-same; hence people's consternation that while the problem is proclaimed to be caused by overborrowing and over-spending, the solution appears to involve further borrowing and spending on an even larger scale. In some regions a different solution is already in place - either by accident or design: state capitalism as found in China, Russia and some of the countries that operate with what are termed 'sovereign wealth funds'. This can be seen as a triumph of aiming for perfection, either dispensing with democratic participation altogether, or effectively limiting or precluding it. In more established democracies the welfare state has suddenly re-emerged, but only for the rich, a somewhat different form of the double movement from that envisaged by Polanyi; but effectively still with the same aim of saving the self-regulating market from its own excesses.

In fact Polanyi himself warned about the fracturing effects of market society, saying that it 'should need no elaboration that a process of undirected change, the pace of which is deemed too fast, should be slowed down, if possible, so as to safeguard the welfare of the community': and commentators as different as Bauman and Theodore Dalrymple (2005) now argue that perhaps the social fabric has been destroyed beyond repair. The socio-cognitive context has become so reliant on an individuated, marketoriented view of the world that people cannot see any solutions other than those couched in terms of a re-invigoration of the market, and a plethora of SME-led, IS/ICT-supported innovations.

\section{The Agora - The Social Entrepreneur, Social Innovation and Civil Society}

What is needed now is not more-of-the-same, the entrepreneur as parvenu; but new ways of seeing, the entrepreneur as pariah. This will involve a re-orientation of what is actually involved in creativity and innovation, stressing the importance of fostering genuinely new ways of seeing in a re-invigorated social context drawing on the possibilities and propensities of IS/ICT. In recent times the concept of a third sector, incorporating charities, voluntary organizations and NGOs, has come to the fore; as distinct from the private and public sectors. This sector is seen as part of the more amorphous and ambiguous 'civil society', which might best be characterized by the following definition from the Centre for Civil Society at the LSE.

Civil society refers to the arena of uncoerced collective action around shared interests, purposes and values. In theory, its institutional forms are distinct from those of the state, family and market, though in practice, the boundaries between state, civil society, family and market are often complex, blurred and negotiated. Civil society commonly embraces a diversity of spaces, actors and institutional forms, varying in their degree of formality, autonomy and power. Civil societies are often populated by organisations such as registered charities, development non-governmental organisations, community groups, women's organisations, faith-based 
organisations, professional associations, trades unions, self-help groups, social movements, business associations, coalitions and advocacy group.

In many regards this is akin to the Agora; initially a specific location in Athens, but later a conceptual space which as Bauman explains was

neither private nor public, but more exactly private and public at the same time. The space where private problems meet in a meaningful way - that is, not just to draw narcissistic pleasures or in search of some therapy through public display, but to seek collectively managed levers powerful enough to lift individuals from their privately suffered misery; the space where such ideas may be born and take shape as the 'public good', the 'just society' or 'shared values'. (1999, pp.3-4)

For Bauman, the history of modern societies has been a long war of attrition 'launched against the agora from the side of the ecclesia'. In other words there has been a sustained effort to curtail or eradicate any space in which issues pertaining to the collective, the shared, the communal, might be raised and discussed. Concomitant with Polanyi's Great Transformation, the encroachment of market society has resulted in the subversion of any claims for legitimacy for the social and communal, fostering the expansion of the operation and calculus of the market flooding into all aspects of human existence - social and personal, the public and the private. Yet the novelty of this as part of modernity and liquid modernity has been in its intensity rather than its actual occurrence, since, as Arendt (1958) pointed out, the pressure from the ecclesia often took the form of efforts to transform the agora 'into an assemblage of shops like the bazaars of oriental despotism'.

If IS/ICT has anything to offer in the present crisis, it is the ways in which new technologies present opportunities for civil society to flourish; the internet, social networking, the blogosphere, wikis and so forth might well be the bases for a renewed if virtual agora: Agora 2.0. But the actual motivation behind some of this technology, particularly the Open Source movement, in fact exemplifies the ways in which the Great Transformation has continued to exert its power. Eric Raymond's The Cathedral and The Bazaar is rightly regarded as the de facto manifesto of the Open Source movement. Yet as Raymond (1997) noted some years later, 'I very nearly called this paper The Cathedral and the Agora, the latter term being the Greek for an open market or public meeting place.' In a brief email exchange with Raymond it became clear that his concept of the agora was profoundly market-oriented and bazaarlike. Thus he distinguished between the 'monetary market' and the market per se which, quoting Drexler and Miller (1988), he explained is 'the sum total of all voluntary interactions': Also stating that the agora is a subset of the market.

Raymond is, of course, entitled to this view; but it should not preclude consideration of the alternative on offer from Arendt and Bauman amongst others. More importantly, if we take up the challenge implicit in Arendt's and Bauman's critique we can see that discussions around IS/ICT-based innovation should indeed engage with the concerns of civil society. In this sense the real social entrepreneurs include those who have sought to counteract the forces of market society; often by giving impetus to the countervailing forces of the double movement. So Beveridge, Bevan, Brandt 
should be regarded as exemplary figures - and it is left to the reader to suggest others of this ilk. Polanyi singled out Robert Owen in this regard, someone who understood that society was the prime phenomenon; wanting to harness the state and the machine to positive effect. He attacked Christianity because it displaced society by individualization. 'He grasped the fact that what appeared primarily as an economic problem was essentially a social one.' He advocated the self-protection of society, something that, Polanyi observes, was in fact incompatible with the economic system itself.

It is well beyond the skills and capabilities of this author to offer anything by way of a definitive explanation for the current crisis, but Polanyi offers a glimpse of what needs to be done to enact some form of transformation that goes beyond policies that amount to little more than cosmetic forms of more-of-the-same. Howells correctly alludes to the socio-cognitive aspects of innovation, but he fails to say whether the socio-cognitive change comes before or after the innovation: I suspect he would argue that either sequence is possible. In terms of the current crisis, however, the sociocognitive change has to start off the process of innovation, with people beginning to grasp that the foisting of the market on society as a whole did not occur naturally, but was the result of a series of deliberate policies and transformations along the lines suggested by Polanyi.

What we are now witnessing is state intervention with a vengeance; but largely on behalf of the rich. This might be simply a case of business-as-usual - albeit in unusual circumstances - but it might also be that there is no way for genuinely new ways of seeing things to find an audience and serious consideration. The babble of the internet remains just that, unless ways can be found to 'leverage' the technology and the participants to a more authoritative level: That will be truly innovative IS/ICT; truly creative use of technology to foster social entrepreneurship that can be encouraged to flourish and have genuine influence, understood in terms of a collective process with firm ethical underpinnings. This will also move innovation-cumentrepreneurship from rational-economic compulsive obsession, to its original and more affirmative meaning. As Camus asserted, it is the artist who discerns a privation of certain things in the world and attempts to recreate the world in acts of creation:

In every rebellion is to be found the metaphysical demand for unity, the impossibility of capturing it, and the construction of a substitute universe. Rebellion, from this point of view, is a fabricator of universes. This also defines art.34

\section{Conclusion - The Post Credit-Crunch Context of Innovation, ICT and SMEs}

What then are the lessons for SMEs in their role as sources of innovation and creativity in the current context of an ICT-oriented network society in which the economic certainties have been replaced by stimulus packages and bail-outs that not even Nobel laureates such as Paul Krugman understand? ${ }^{16}$ At the very least there must be a reconsideration of concepts such as creativity, innovation, and entrepreneurialism. These will not disappear as the world moves towards ever greater rationality and

\footnotetext{
${ }^{16}$ Paul Krugman column, New York Times, February 10, 2009.
} 
planning, on the contrary, rational models themselves have been found wanting in the extreme. Bauman's concept of liquid modernity centres on this; the current context of illiquidity makes it even more evident.

This has severe implications for IS/ICT and computability since models that seem to indicate the possible perfection of calculability and computability of complex decisions have proved wanting. Indeed there are good reasons to point to computer-based models and ICT-based transaction systems as very much part of the problem. Moreover the flow of information, given the reality of ICT, the internet and so on, has played a significant role in persuading people of the power and promise of innovation; with innovation having become an end in itself. Thus leveraging IS/ICT is perhaps a misleading image since it can be taken to imply that use of ICTs by SMEs is inevitably going to be 'a good thing', resulting in significant benefits derived from small, agile sources and resources. The IS world's enthusiasm for knowledge management has often exhibited this partiality in both regards; with knowledge seen as something that is inherently perfectible and manageable, and with more meaning better. The current crisis, and its precursors in scandals such as Enron and WorldCom, demonstrates the darker aspects of knowledge management as well as the risks and dangers of leveraging.

In the light of all these developments the spirit of the entrepreneur has to be recognized as something that will always be required, but Drucker's dream of a society of entrepreneurs and SMEs may in fact be far more of a nightmare, made even worse with the advent of ICTs.

What is needed is a re-interpretation or revision of our concepts of innovation. We have lived through a period where inventions were themselves commodified, with even cases of people inventing things and then looking for the problem for which the invention might be a saleable solution. Using Winston's terms this is a case of the brake disappearing, and the accelerator being full on for innovation; moving even minor competences to fully fledged, marketable performances. Socio-cognitively, as Howell suggests, innovation and creativity came to encompass financial sleights of hand whereby liabilities were treated as assets, and other such absurdities. We now see the necessity to move away from this, while retaining an impetus in favour of creativity amidst a modernity that is not characterized by order, planning and calculation; but rather by complexity, chaos and turbulence. This may also offer an opportunity to rebalance the forces behind the double movement, and ICT has a key part to play in this, particularly drawing on the inspiration offered by the Open Source movement and its derivatives. (What can be termed Mutuality 2.0, but that is a subject for whole new paper.)

The context within which SMEs now operate requires a rethinking of their role as sources of innovation and creativity; not least because many of them will be unable to attract the investments needed to progress their ideas. Here again ICT has a part to play since it has resulted in fractional transaction costs and allowed new forms of networking to develop that might provide alternative routes to obtain funding or other resources - again Open Source is an archetype. Crises represent opportunities for entrepreneurs to flourish, but the present one also offers the prospect to change the way in which innovation, creativity, and entrepreneurship are envisaged and nurtured. The literal translation of Der Unternehmer is The Undertaker; and it may now be time to inter one form of innovation in favour of another: Or as Einstein noted in the quote above; it may be time for us to attend more to the gift and less to the servant. 


\section{References}

Arendt, H.: The Origins of Totalitarianism. Harcourt, San Diego (1994, orig 1951)

Arendt, H.: The Human Condition. University of Chicago Press, Chicago (1998, orig 1958)

Bauman, Z.: In Search of Politics. Polity, Cambridge (1999)

Bauman, Z.: Liquid Modernity. Polity, Cambridge (2000)

Bauman, Z.: Wasted Lives. Polity, Cambridge (2004)

Bryant, A.: Liquid Modernity, Complexity and Turbulence. Theory, Culture \& Society 24, 127-136 (2007)

Bryant, A., Pollock, G., Bauman, Z., Metzger, G.: Liquid Arts. Theory, Culture \& Society 24(1) (2007)

Calvino, I.: Invisible Cities. Harcourt, Orlando (1974)

Camus, A.: The Rebel. Penguin, Harmondsworth (2000, orig 1951)

Castells, M.: The Rise of the Network Society: Economy, Society and Culture. Blackwell, Oxford (2000, orig 1996)

Dalrymple, T.: Our Culture What's Left of it. Ivan Dee, London (2005)

Denning, P.: The Social Life of Innovation. Communications of the ACM 47(4), 15-19 (2004)

Drucker, P.: Innovation \& Entrepreneurship, 2nd revised edn. Butterworth-Heinemann, Oxford (1994)

Edwards, M.: Just Another Emperor? The Myths and Realities of Philanthrocapitalism. The Young Foundation/DEMOS, London (2008)

Howells, J.: The Management of Innovation \& Technology. SAGE, London (2005)

Langlois, R.: Schumpeter and the Obsolescence of the Entrepreneur. Announced as due to appear in Advances in Austrian Economics (2002),

http: / / ideas.repec.org/p/uct/uconnp/2002-19.html

Miller, M.S., Drexler, K.E.: The Agoric Papers. In: Huberman, B. (ed.) First published in The Ecology of Computation. Elsevier Science Publishers/North-Holland (1988),

http: / / www.agorics.com/Library/agoricpapers.html

Peters, T., Waterman, R.: In Search of Excellence. Harper \& Row, New York (1982)

Polanyi, K.: The Great Transformation. Beacon, Boston (2001, orig 1944)

Raymond, E.: The Cathedral and the Bazaar. First given at the Linux Kongress, 1997; subsequently republished and revised on several occasions and in several places; the version referenced here is the title essay in Raymond's book, The Cathedral and The Bazaar: Musings on Linux and Open Source by an Accidental Revolutionary. O'Reilly (page references are for the latter edition) (1997)

Sennett, R.: The Corrosion of Character. Norton, London (1999)

Winston, B.: Media, Technology \& Society. Routledge, London (1998) 